\title{
Scientific Approach in K-13; the Impact on the Quality of the Learning Process and Outcomes in MAN
}

\author{
Agus Pahrudin \\ Raden Intan State Islamic University, Bandar Lampung, Indonesia \\ agus.pahrudin@radenintan.ac.id \\ Dona Dinda Pratiwi \\ Raden Intan State Islamic University, Lampung, Indonesia \\ donadinda@radenintan.ac.id
}

\begin{abstract}
The Kurikulum 2013 -Indonesia's novel Curriculum invented in 2013- is implemented through activity-based learning using a scientific approach. Curriculum changes do not only occur in the dimensions of the plan/document, but in its implementation in the quality of the process which has an impact on learning outcomes. This research aims to determine the implementation of the Kurikulum 2013 scientific approach and its impact on the quality of the learning processes and outcomes at MAN in Lampung Province. The research uses a mixed methods with sequential mixed methods design. The respondents consisted of 26 teachers and 126 students. Data were collected by conducting interview, observation, documentation, and questionnaire. The validity was tested by Pearson's validity and Cronbach Alpha reliability. The results showed that teachers can apply a scientific approach to the implementation of the Kurikulum 2013 well. It can be seen from the teacher's ability to prepare lesson plans, though there are some teachers (working period of 21 to 30 years) who are constrained during the learning process, such as observing the learning and not being able in presenting the media. The scientific approach has a very good impact on the quality of the learning process and outcomes. It can be seen by the increase in student learning outcomes.
\end{abstract}

Keywords: Curriculum 2013; scientific approach; learning process and outcomes 


\begin{abstract}
Abstrak
Kurikulum 2013 diimplementasikan melalui pembelajaran berbasis aktivitas dengan menggunakan pendekatan saintifik. Perubahan kurikulum tidak hanya terjadi pada dimensi rencana/dokumen, melainkan implementasinya dalam kualitas proses yang berdampak pada hasil pembelajaran. Tujuan penelitian untuk mengetahui implementasi pendekatan saintifik kurikulum 2013 dan dampaknya terhadap kualitas proses dan hasil pembelajaran pada MAN di Provinsi Lampung. Metode penelitian menggunakan mixed method dengan desain sequential mixed methods . Total responden terdiri dari 26 guru dan 126 siswa. Data dikumpulkan dengan wawancara, observasi, dokumentasi, dan angket. Keabsahan diuji dengan validitas Pearson dan reliabilitas Cronbach Alpha. Hasil penelitian menunjukkan bahwa guru dapat menerapkan pendekatan saintifik dalam implementasi kurikulum 2013 dengan baik. Hal ini terlihat dari kemampuan guru menyusun RPP, namun ada beberapa guru (masa kerja $21 \mathrm{sd} 30$ tahun) yang terkendala pada saat proses pembelajaran, seperti hal mengamati dan kurang dalam membawakan media. Pendekatan saintifik berdampak sangat baik terhadap kualitas proses dan hasil pembelajaran, terlihat dengan meningkatnya hasil belajar siswa.
\end{abstract}

Kata kunci: Kurikulum 2013; saintifik proses; dan hasil belajar

\title{
A. Introduction
}

The non-optimal scientific development of student potential occurs because students gain more knowledge or science through explanations from the teacher. This of course has an impact on the low quality of education graduates (Jacobs \& Renandya, 2019; Jilin, 2017; Raharjo, 2013; Tan \& Low, 2019; Teo et al., 2013). In fact, the characteristics of the current 2013 curriculum (K-13) is using an integrative scientific and thematic approach that recommend learning that actualizes all potential and raises student motivation. This approach aims to make students gain experience and be trained directly to seek knowledge that is learned independently (Pahrudin et al., 2020; Permendikbud, 2016; Purwanto et al., 2020; Wijaya Kuswanto \& Dinda Pratiwi, 2020). The scientific approach is a golden step for the development of skills, attitudes, and knowledge to obtain graduates who are reliable and have noble character needs guidance so that students are creative, innovative, and productive so that students are ready to compete globally(Ho, 2018; Muslim, 2017; Rusman, 2017; Saddhono, 2018). If the stages of the scientific approach are carried out well, learning will be centered on students and students will get used to higher-order thinking, the ability to solve problems will develop, and student learning outcomes will increase. (Fatmawati et al., 2018; Pratiwi, 2019) 
This condition is of course contrary to the goal of changing the K-13. The curriculum itself has undergone several revisions, starting from a revision of learning tools, approaches, to assessment scales(Saddhono, 2018). In the revised K-13 or what is currently often referred to as K-13, it does not make the scientific approach the only learning method, but if it is used the arrangement does not have to be sequential. The existence of teacher freedom in processing the learning model at K-13 requires teachers to be more qualified and have high creativity.

The quality of education is determined by good planning and management so that the learning process can achieve educational goals. The teacher as a facilitator, motivator, and student partner during the learning process play an important role(Siskandar, 2017). In addition, the quality of education is of course also supported by a good, dynamic, and open curriculum, and can accommodate skills globally. Thus, a good curriculum and quality teachers can have an impact on improving the quality of education(Sumiarwan, 2017).

The description above is supported by previous research, that scientific learning needs to be maintained as a basis for shaping scientific knowledge to be objective and subjective simultaneously(Jedemark, 2019). Meanwhile, curriculum changes need to be implemented because normative principle is still clearly prominent so that student learning outcomes are still fixated on aspects of knowledge(Roth \& Friesen, 2014). By implementing the K-13, it is hoped that the goals in shaping the character of the nation can be achieved (Judge, 2017).

For this reason, this research needs to be done to describe how the application of the scientific approach to K-13 in the MAN environment and its impact on the quality of the learning process as seen from the ability of teachers to prepare lesson plans and teaching and how it impacts student learning outcomes.

\section{B. Discussion}

\section{Research methods}

This study uses a sequential mixed methods design (John W. Creswell, 2017; Mason et al., 2020; Pelto, 2015). The population in this study were teachers and students of MAN 1 
Agus Pahrudin dan Dona Dinda Pratiwi

Bandar Lampung (MAN 1 BL) and MAN 1 Pesisir Barat (MAN 1 PSB). The following are the research methods in Table 1.

Table 1. Research Methods

\begin{tabular}{ccc}
\hline Method & Qualitative & Quantitative \\
\hline Sample & Informants: 13 Teachers & $\begin{array}{c}\text { Respondents: } 13 \\
\text { teachers and } 63 \\
\text { students }\end{array}$ \\
\hline Sampling Technique & Pusposive & Cluster Random \\
\hline Instrument & Main; Researcher, & Observation \\
& Help; Interview and & (checklist) and \\
& Documentation & Questionnaire \\
\hline Validity & Triangulation Method & Product Moment \\
\hline Reliability & Audit & Alpha Croncbanch \\
\hline Data analysis & Data reduction & Likert scale \\
\hline
\end{tabular}

\section{Description of Research Data}

\section{a. Qualitative Data Descriptions}

Following are the results of the triangulation of data in Table 2 obtained from 26 teachers:

Table 2. Interview Triangulation Data and Documentation

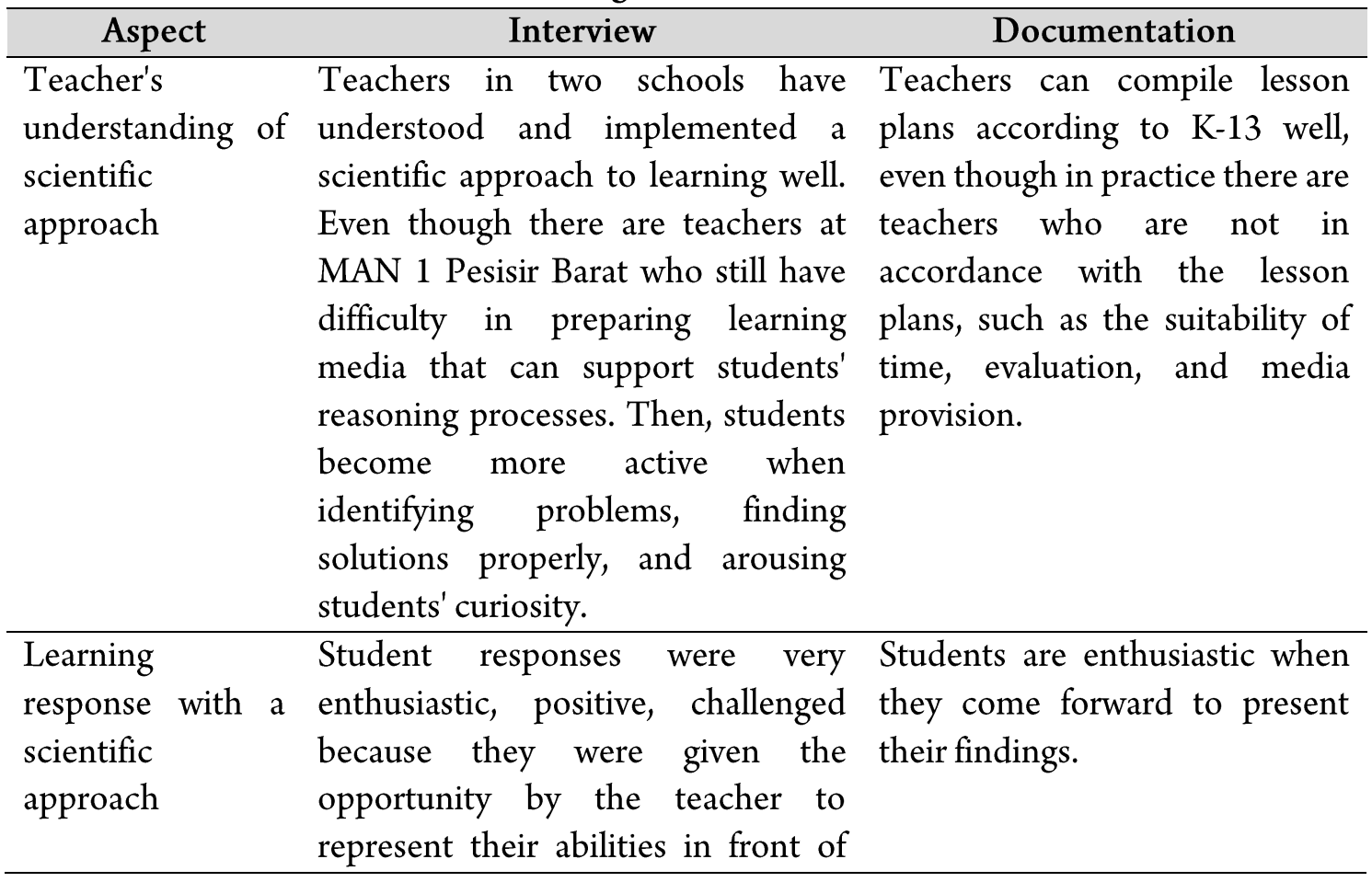


their friends. Scientific approach is suitable for MIA subjects, although some students are still a little slow in responding.

Scientific impact According to teachers in two The scores of students who on the quality of schools, science has had a good reach the KKM are more than the process and impact. This can be seen from the those under the KKM. learning outcomes accumulation of better scores related to cognitive, psychomotor, and affective aspects. Students are more able to find important concepts for their critical thinking skills process.

Barriers to the use Raising the enthusiasm of students Less learning media used by of science to ask questions, representing the teachers. results for shy children, it takes time and high creativity for teachers and infrastructure is still lacking.

\section{b. Quantitative Data Descriptions}

This analysis was carried out by using the Likert scale test to determine the impact of the scientific approach on the quality of the process and learning outcomes at the MAN level.

\section{1) Ability to Design RPP (Lesson Plan)}

This instrument is measured by observation, the researcher provides a checklist of components in accordance with the lesson plan. The instrument contains seven components of the teacher's ability to prepare lesson plans, which are submitted to 13 teachers for each school. Following are the results of data analysis on the ability to compile RPP in Table 3.

Table 3. Observation Results Ability to Prepare RPP

\begin{tabular}{|c|c|c|c|c|c|c|c|c|c|}
\hline \multirow{2}{*}{$\begin{array}{l}\mathrm{N} \\
\mathbf{o} .\end{array}$} & \multirow{2}{*}{ Category } & \multicolumn{4}{|c|}{ MAN 1 BL } & \multicolumn{4}{|c|}{ MAN 1 PSB } \\
\hline & & F & $\mathrm{X}$ & $\begin{array}{l}f \\
(x)\end{array}$ & $M=\frac{\sum f(x)}{f}$ & $\mathbf{F}$ & $\mathrm{X}$ & $\begin{array}{c}f \\
(x)\end{array}$ & $M=\frac{\sum f(x)}{f}$ \\
\hline 1 & Very good & 33 & 5 & 165 & \multirow{5}{*}{$M=375 / 91$} & 17 & 5 & 85 & \multirow{5}{*}{$M=349 / 91$} \\
\hline 2 & Well & 36 & 4 & 144 & & 42 & 4 & 168 & \\
\hline 3 & Enough & 22 & 3 & 66 & & 32 & 3 & 96 & \\
\hline 4 & Not good & 0 & 2 & 0 & & 0 & 2 & 0 & \\
\hline 5 & Not very good & 0 & 1 & 0 & & 0 & 1 & 0 & \\
\hline & Total & 91 & & 375 & 4.1 & 91 & & 349 & 3.84 \\
\hline
\end{tabular}


The data in table 3 shows that the comparison of the results obtained at MAN $1 \mathrm{BL}$ was 4.1 with very good criteria, while MAN 1 PSB was 3.84 with good criteria. Thus, it can be concluded that the ability of teachers to prepare lesson plans in MAN 1 BL and MAN 1 PSB is in a good category.

\section{2) Ability in Implementing Learning}

The instrument is measured through the observation sheet. Practically, the researcher providing a checklist on the sheet that is in accordance with the implementation of learning carried out by the teacher. This instrument contains 18 components that cover the teacher's ability to carry out learning. The following are the results of data analysis on the ability to carry out learning in Table 4.

Table 4. Observation Results of Ability in Implementing Learning

\begin{tabular}{|c|c|c|c|c|c|c|c|c|c|}
\hline \multirow{2}{*}{ No } & \multirow[b]{2}{*}{ Category } & \multicolumn{4}{|c|}{ MAN 1 BL } & \multicolumn{4}{|c|}{ MAN 1 PSB } \\
\hline & & $\mathbf{F}$ & $\mathrm{X}$ & $f(x)$ & $M=\frac{\sum f(x)}{f}$ & $\mathbf{F}$ & $\mathrm{X}$ & $f(x)$ & $M=\frac{\sum f(x)}{f}$ \\
\hline 1 & Very good & 131 & 5 & 655 & \multirow{5}{*}{$\begin{array}{l}M= \\
1047 / 234\end{array}$} & 64 & 5 & 320 & \multirow{5}{*}{$\begin{array}{l}M= \\
940 / 234\end{array}$} \\
\hline 2 & Well & 83 & 4 & 332 & & 111 & 4 & 444 & \\
\hline 3 & Enough & 20 & 3 & 60 & & 58 & 3 & 174 & \\
\hline 4 & Less & 0 & 2 & 0 & & 1 & 2 & 2 & \\
\hline 5 & Not very good & 0 & 1 & 0 & & 0 & 1 & 0 & \\
\hline & Total & 234 & & 1047 & 4.47 & 234 & & 940 & 4.02 \\
\hline
\end{tabular}

Based on the data in table 4, it can be seen that the comparison of the results obtained at MAN $1 \mathrm{BL}$ is 4.47, while MAN 1 PSB is 4.02, both of which fall into the very good criteria. It can be concluded that the ability of MAN $1 \mathrm{BL}$ and MAN 1 PSB teachers in implementing learning is very good.

\section{3) Student Response}

Student responses were measured by a questionnaire totaling 40 items ranging from 1 to 4 and submitted to 63 students for each school. The following are the results of the analysis of the student response questionnaire data in Table 5. 
Table 5. Results from Student Questionnaire Against the Implementation of the Scientific Approach

\begin{tabular}{|c|c|c|c|c|c|c|c|c|c|}
\hline \multirow{2}{*}{ No } & \multirow{2}{*}{ Category } & \multicolumn{4}{|c|}{ MAN 1 BL } & \multicolumn{4}{|c|}{ MAN 1 PSB } \\
\hline & & $\mathbf{F}$ & $\mathrm{X}$ & $f(x)$ & $M=\frac{\sum f(x)}{f}$ & $\mathbf{F}$ & $\mathrm{X}$ & $f(x)$ & $M=\frac{\sum f(x)}{f}$ \\
\hline 1 & Strongly agree & 793 & 4 & 3172 & \multirow{4}{*}{$\begin{array}{l}M= \\
7689 / 2520\end{array}$} & 961 & 4 & 3844 & \multirow{4}{*}{$\begin{array}{c}M= \\
7912 / 2520\end{array}$} \\
\hline 2 & Agree & 1147 & 3 & 3441 & & 1062 & 3 & 3186 & \\
\hline 3 & Disagree & 496 & 2 & 992 & & 385 & 2 & 770 & \\
\hline 4 & $\begin{array}{l}\text { Strongly } \\
\text { Disagree }\end{array}$ & 84 & 1 & 84 & & 112 & 1 & 112 & \\
\hline & Total & 2520 & & 7689 & 3.05 & 2520 & & 7912 & 3.15 \\
\hline
\end{tabular}

Based on table 5, it can be seen that the comparison of the results obtained at MAN 1 BL is 3.05, while MAN 1 PSB is 3.15, both of which fall into good criteria. It can be concluded that the responses given by students of MAN 1 BL and MAN 1 PSB were good for the implementation of the scientific approach.

4) Teacher Response to the Implementation of the Scientific Approach

Teacher responses were measured using a questionnaire totaling 40 items, ranging from 1 to 4, submitted to 13 teachers for each school. The following is in Table 6.

Table 6. Teacher Questionnaire Results on the Implementation of the Scientific Approach

\begin{tabular}{|c|c|c|c|c|c|c|c|c|c|}
\hline \multirow{2}{*}{$\begin{array}{l}\mathbf{N} \\
\mathbf{o}\end{array}$} & \multirow{2}{*}{ Category } & \multicolumn{4}{|c|}{ MAN 1 BL } & \multicolumn{4}{|c|}{ MAN 1 PSB } \\
\hline & & $\mathbf{F}$ & $\mathrm{X}$ & $f(x)$ & $M=\frac{\sum f(x)}{f}$ & $\mathbf{F}$ & $\mathrm{X}$ & $f(x)$ & $M=\frac{\sum f(x)}{f}$ \\
\hline 1 & Strongly agree & 210 & 4 & 840 & \multirow{4}{*}{$\begin{array}{l}M= \\
1633 / 520\end{array}$} & 226 & 4 & 904 & \multirow{4}{*}{$\begin{array}{c}M= \\
1712 / 520\end{array}$} \\
\hline 2 & Agree & 200 & 3 & 600 & & 230 & 3 & 690 & \\
\hline 3 & Disagree & 83 & 2 & 166 & & 54 & 2 & 108 & \\
\hline 4 & Strongly Disagree & 27 & 1 & 27 & & 10 & 1 & 10 & \\
\hline \multirow{2}{*}{\multicolumn{2}{|c|}{ Total }} & & & 163 & \multirow[t]{2}{*}{3.14} & & & 171 & \multirow[t]{2}{*}{3.29} \\
\hline & & 520 & & 3 & & 520 & & 2 & \\
\hline
\end{tabular}

Based on table 6, it can be seen that the comparison of the results obtained at MAN 1 BL is 3.14, while MAN 1 PSB is 3.29 , both of which fall into the good criteria. It can be 
Agus Pahrudin dan Dona Dinda Pratiwi

concluded that the responses given by teachers of MAN 1 BL and MAN 1 PSB were good for the implementation of the scientific approach.

\section{5) Learning outcomes}

The impact of implementing the scientific approach on student learning outcomes can be seen from the final semester results listed in Table 7

Table 7. Data on Student Learning Outcomes

\begin{tabular}{llcc}
\hline No. & School & Total students & Average Learning Outcomes \\
\hline 1 & MAN 1 Bandar Lampung & 63 & 76,412 \\
\hline 2 & MAN 1 West Coast & 63 & 78,730 \\
\hline \multicolumn{3}{c}{ Overall average } \\
\hline
\end{tabular}

Based on the data table 7, it can be seen that the overall average student learning outcomes of MAN 1 Bandar Lampung and MAN 1 Pesisir Barat are 77.571. While the average student learning outcomes of MAN 1 Pesisir Barat were higher than those of MAN 1 Bandar Lampung. When compared with the KKM learning scores, the average learning outcomes of the two schools were declared complete.

\section{Research Data Narrative}

The application of the K-13 scientific approach is seen from the ability of teachers to compile lesson plans and carry out learning that has been done well. The lesson plan (RPP) contains the activity plan from the beginning to the evaluation planning appropriately. In practice, teachers are more innovative in managing the learning process so that the target KKM learning is achieved. It can be seen that the teacher applies the scientific learning model, namely PBL. Teachers always apply innovative learning models, stimulate students to analyze problems, and explore their cognitive abilities to solve a problem. This is in line with the view that teachers need to always see directly, direct in-depth regarding student activities when interacting effectively (Brandenburg, 2016; Brooks et al., 2019; Rogers, 2019; Thapa et al., 2016; Webster \& Whelen, 2019).

These results are supported by the data analysis checklist sheet. However, these results differ from interview and documentation data. There are still teachers who have difficulty in preparing the media, especially teachers in science studies, such as mathematics and science. Meanwhile, teachers in the field of social studies, religion, and language are sufficiently able to explore learning media and time management during the learning process. Judging from the teacher's profile, the work period of 11 to 20 years is the best in preparing lesson plans, class 
management, providing teaching aids both manual and software. Meanwhile, teachers with a working period of 0 to 10 years are quite capable of managing the class, 21 to 30 years of age have difficulty providing teaching aids with the help of software/applications. Then from the documentation data, some teachers do not use the lesson plan as a guide in learning activities and have difficulties in providing learning media/teaching aids. The teacher's ability to prepare lesson plans and carry out learning certainly supports the quality of the learning process (Sumiarwan, 2017).

The explanation above is an obstacle felt by the teacher. It is still difficult to manage time, grow motivation, and prepare learning media or infrastructure. So, there needs to be a followup to minimize existing problems, both from the government, then forwarded to the teacher. Scientific applications have received good responses. This is evidenced from the results of interviews, documentation, and questionnaires. The teacher challenges students to find something related to the lesson so that students are motivated to hone their cognitive abilities in terms of exploring and analyzing a problem. The teacher also always allows students to present their findings in front of the class so that students are more courageous in expressing their opinions. The existence of this action certainly stimulates students to hone their cognitive abilities in terms of exploring and analyzing a problem.

Based on the learning outcome data, scientific learning is suitable to be implemented to improve student learning outcomes. This is in accordance with DeVito's theory (Ahmdi, N., Peter, L., Lubart, T., \& Besançon, 2019; Faisal, 2014; Gregerson et al., 2013; Stacey et al., 2018), which explained that the scientific approach is the development of scientific thinking skills as well as increased creative thinking skills and a student's sense of inquiry. Solving problems in learning will be done objectively. The point is when students solve student problems using an inductive approach. This is the impact of scientific learning when the problem-solving process starts from specific things to things that are general in nature. Thus, this is in accordance with the scientific theory which emphasizes more on process skills, such as observing, classifying, measuring, predicting, explaining, and concluding (Beghetto \& Corazza, 2019; Gosper et al., 2014; Ihsan, 2014; Peppler, 2017; Yu et al., 2020).

Thus, the application of the scientific approach in the implementation of the 2013 Curriculum can help to create learning that meets process standards to improve the quality of learning. It can also help to achieve complete learning and educational goals, including 
attitudes (religious attitudes and social attitudes), knowledge, and skills. Activities developed in a scientific approach can trigger the emergence and creation of various learning experiences obtained by students by involving all five senses, physically and psychologically so that students develop their various potentials.

\section{Conclusion}

Teachers are able to apply the scientific approach in implementing the 2013 curriculum well. This can be seen from the results of the teacher's ability to prepare lesson plans and carry out learning in class. Both the teachers in MAN 1 BL and MAN 1 PSB already know and understand the theories, concepts and use a scientific approach. Understanding of techniques and theories about the scientific approach is not in doubt. A very valuable finding for improvement is that there are still some teachers who don't display the media very much during the learning process. In addition, there are teachers who do not carry out the process in accordance with the RPP even though in the context of the scientific approach, the ability and willingness to use learning media is a necessity.

The scientific approach has a good impact on the quality of the learning process. The teacher is always active in motivating, stimulating students to think scientifically, and allowing students to represent their findings. Thus, the self-confidence of each student appears. Students are enthusiastic about the learning process. Student abilities in critical thinking by observing, questioning, reasoning and communicating skills are also increasing. This certainly has a good impact on student learning outcomes, indicated by the average value of learning outcomes is above the KKM, better than before.

Finally, the research suggests that teachers need to consider the implementation time, the suitability of the lesson plan with the implementation of learning, and the availability of media to support learning. The freedom of teachers to manage classes at K-13 certainly forces teachers to always be creative in planning and implementing learning that can increase and actualize all the potential that students have. Because no matter how great a curriculum is, if the teacher doesn't understand it and is unable to implement it, then it doesn't have any meaning. Therefore, in the context of curriculum implementation, in the end, it returns to the ability of teachers who are at the forefront of carrying out the quality of the learning process as a real curriculum which has an impact on the quality of results (Curriculum as product). 


\section{REFERENCES}

Beghetto, RA, \& Corazza, GE (2019). Dynamic Perspectives On Creativity: New Directions For Theory, Research, And Practice In Education.

Brandenburg, R. (2016). Brandenburg et al 2016 Teacher Education - Innovation Intervention \& Impact.

Brooks, AL, Eds, NV, Coulson, G., \& Ferrari, D. (2019). Interactivity, Game Creation, Design, Learning, and Innovation. In Interactivity, Game Creation, Design, Learning, and Innovation (Vol.265). https://doi.org/10.1007/978-3-030-06134-0

Faisal. (2014). Success in Guarding 2013 Curriculum in Elementary School.

Fatmawati, L., Sukidin, S., \& Suyadi, B. (2018). Differences in Student Learning Outcomes through a Conventional Approach with a Scientific Approach in the Basic Competencies of Management Functions of Class X Students at Public High School 4 Jember, 2016/2017 Academic Year. JOURNAL OF ECONOMIC EDUCATION: Scientific Journal of Educational Sciences, Economics and Social Sciences, 11 (2), 134. https://doi.org/10.19184/jpe.v11i2.6460

Gosper, M., Ifenthaler, D., Technologies, UL, \& Education, H. (2014). Curriculum Models for the 21st Century. In Curriculum Models for the 21st Century. https://doi.org/10.1007/978-1-4614-7366-4

Gregerson, MB, Snyder, HT, \& Kaufman, JC (2013). Teaching creatively and teaching creativity. In Teaching Creatively and Teaching Creativity. https://doi.org/10.1007/978-1-4614-5185-3

Hakim, L. (2017). Analysis of Differences Between Curriculums. The Scientific Journal of Didactics, 17 (2), 280-292. https://doi.org/10.22373/jid.v16i1.590.5

Ho, ONK (2018). Rethinking the Curriculum. In Rethinking the Curriculum. https://doi.org/10.1007/978-981-10-8902-2

Ihsan, RS and H. (2014). The Scientific Approach in the Implementation of the 2013 Curriculum Based on the Study of Learning Psychology Theory. Edutech, 1 (2), 183195.

Jacobs, GM, \& Renandya, WA (2019). Student centered cooperative learning: Linking concepts in education to promote student learning.

Jedemark, M. (2019). A scientific approach in the assessment of the school-based part of the teacher education program in Sweden. Journal of Curriculum Studies, 51 (3), 420-436. https://doi.org/10.1080/00220272.2019.1567820 
Jilin, L. (2017). Curriculum and practice for children's contextualized learning. In Curriculum and Practice for Children's Contextualized Learning. https://doi.org/10.1007/978-3662-55769-3

John W. Creswell, CNP (2017). Qualitative Inquiry and Research Design (International Student Edition): Choosing Among Five Approaches. SAGE Publications.

Mason, W., Morris, K., Webb, C., Daniels, B., Featherstone, B., Bywaters, P., Mirza, N., Hooper, J., Brady, G., Bunting, L., \& Scourfield, J. (2020). Toward Full Integration of Quantitative and Qualitative Methods in Case Study Research: Insights From Investigating Child Welfare Inequalities. Journal of Mixed Methods Research, 14 (2), 164-183. https://doi.org/10.1177/1558689819857972

Muslim, SR (2017). The Influence of Using the Project Based Learning Model on the Mathematical Problem Solving Ability of Students. Supremum Journal of Mathematics Education, 1 (2), 88-95.

Pahrudin, A., Ahid, N., Huda, S., Ardianti, N., Putra, FG, Anggoro, BS, \& Joemsittiprasert, W. (2020). The effects of the ECIRR learning model on mathematical reasoning ability in the curriculum perspective 2013: Integration on student learning motivation. European Journal of Educational Research, 9 (2), 675-685. https://doi.org/10.12973/eujer.9.2.675

Pelto, PJ (2015). What is so new about mixed methods? Qualitative Health Research, 25 (6), 734-745. https://doi.org/10.1177/1049732315573209

Peppler, K. (2017). Critical Literacies. In The SAGE Encyclopedia of Out-of-School Learning. https://doi.org/10.4135/9781483385198.n67

Permendikbud. (2016). Permendikbud No. 22 of 2016. 1-15.

Pratiwi, DD (2019). Development of Linear Algebra Teaching Materials Based on Islamic Values with a Scientific Approach. Decimal: Mathematical Journal, 2 (2), 155-163. https://doi.org/10.24042/djm.v2i2.4200

Purwanto, BE, Jatmiko, A., Pahrudin, A., Munifah, Wardhani, S., Purnama, S., \& Joemsittiprasert, W. (2020). The Implementation Of Cooperative Learning To Developed Management Of Language Learning System. Journal for the Education of Gifted Young Scientists, 8 (1), 379-392. https://doi.org/10.17478/jegys.675251

Raharjo, SB (2013). Evaluation of Education Quality Trends in Indonesia. Journal of Educational Research and Evaluation, 16 (2), 511-532. https://doi.org/10.21831/pep.v16i2.1129

Rogers, KB (2019). Curriculum for high ability learners: issues, trends, and practices. In Asia Pacific Journal of Education (Vol. 39, Issue 3). https://doi.org/10.1080/02188791.2018.1504857 
Roth, WM, \& Friesen, N. (2014). History and the relationship between scientific and pedagogical knowledge: anatomy lectures then and now. Journal of Curriculum Studies, 46 (2), 180-200. https://doi.org/10.1080/00220272.2013.773597

Rusman. (2017). Learning \& Learning Process-Oriented Education Standards. Prenadamedia Group.

Saddhono, K. (2018). Implementation of the Revised 2013 Curriculum through the Implementation of the Scientific Approach in Pacitan District High Schools. https://doi.org/10.31227/OSF.IO/W5Z62

Siskandar, -. (2017). Analysis of the Role of Teachers and Principals of Madrasahs in Implementing the 2013 Curriculum. Sociohumanities, 19 (2), 26-36. https://doi.org/10.24198/sosiohumaniora.v19i2.12194

Stacey, O., De Lazzari, G., Grayson, H., Griffin, H., Jones, E., Taylor, A., \& Thomas, D. (2018). The Globalization of Science Curricula. In IEA Research for Education (Vol. 3). https://doi.org/10.1007/978-3-319-71532-2

Sumiarwan, I. (2017). The Effect of 2013 Curriculum Policy Implementation on Learning Management to Achieve Learning Quality. Khazanah Akademia, 01 (01), 1-8.

Tan, O., \& Low, WLE (2019). Teacher Education in the 21st Century. In Teacher Education in the 21st Century. https://doi.org/10.5772/intechopen.77621

Teo, JE, Deng, Z., Lee, CK-E., \& Lim-ratnam, C. (2013). Globalization and the Singapore Curriculum. https://doi.org/10.1007/978-981-4451-57-4

Thapa, A., Cohen, J., Guffey, S., Higgins-D'Alessandro, A., Ozkan, M., Balci, S., Kayan, S., Is, E., Yoon, J., Järvinen , T., \& Nilsen, T. (2016). Teacher Quality, Instructional Quality and Student Outcomes. Relationships Across Countries, Cohorts and Time (A Series of Indepth Analyzes Based on Data of the International Association for the Evaluation of Educational Achievement (IEA)). In Comparative Education (Vol. 52, Issue 4). https://doi.org/10.1080/03050068.2016.1220128

Webster, RS, \& Whelen, JD (2019). Rethinking Reflection and Ethics for Teachers. In Rethinking Reflection and Ethics for Teachers. https://doi.org/10.1007/978-981-329401-1

Wijaya Kuswanto, C., \& Dinda Pratiwi, D. (2020). Thematic-Based Development of Physical Education Teaching Materials for Early Childhood. Al-Athfal: Journal of Children's Education, 6 (1), 55-68. https://doi.org/10.14421/al-athfal.2020.61-05

Yu, S., Ally, M., \& Tsinakos, A. (2020). Bridging Human and Machine: Future Education with Intelligence Emerging Technologies and Pedagogies in the Curriculum. Springer Nature Singapore Pte Ltd. 
